\title{
Solving the dilemma of transforming landslide hazard maps into effective policy and regulations
}

\author{
J. V. DeGraff \\ USDA Forest Service, Clovis, CA, USA \\ Correspondence to: J. V. DeGraff (jdegraff@fs.fed.us) \\ Received: 20 October 2011 - Accepted: 24 November 2011 - Published: 6 January 2012
}

\begin{abstract}
As geoscientists, we often perceive the production of a map or model to adequately define landslide hazard for an area as the answer or end point for reducing risk to people and property. In reality, the risk to people and property remains pretty much the same as it did before the map existed. Real landslide risk reduction takes place when the activities and populations at risk are changed so the consequences of a landslide event results in lower losses. Commonly, this takes place by translating the information embodied in the landslide hazard map into some change in policy and regulation applying to the affected area. This is where the dilemma arises. Scientific information generally has qualifications, gradations, and conditions associated with it. Regulations are necessarily written in language that tries to avoid any need for interpretation. Effectively incorporating geologic information into regulations and ordinances requires continued involvement with their development and implementation. Unless geoscientists are willing to participate in that process, sustainable risk reduction is unlikely to occur.
\end{abstract}

\section{Introduction}

A significant amount of research, especially during the last two decades, has improved our ability to reduce landslide hazards. Many new or improved methodologies have advanced our ability to identify where landslides are likely to occur (Chacon et al., 2006). This can foster a perception that production of a map adequately defining landslide hazard in an area represents the answer, or end point, for reducing risk to people and property posed by landslide hazards. In reality, the risk to people and property remains the same as it did before the map was produced. Actual landslide risk reduction takes place when the activities and behavior of populations at risk are changed so the consequences of a landslide event result in no or lower losses (DeGraff, 2000). Typically, this takes place by translating the information embodied in the landslide hazard map into policies and regulations applying to the affected area. This is where the dilemma arises. Scientific information necessarily has qualifications, limitations, and conditions associated with it. Policy is implemented through laws and regulations written in a language that tries to avoid or limit the need for interpretation. In other words, it can be difficult to incorporate normal scientific uncertainty into effective measures influencing societal actions.

Producing a landslide hazard map is really the starting point rather than the end point in landslide risk reduction. The map represents the beginning of an educational process requiring a change in how the affected society behaves. While all members of the affected society should be involved, it is vital that scientific and engineering professionals be involved with translating the landslide hazard information. Without these individuals being engaged in this process, it is unlikely that development and implementation of policy and regulation to reduce landslide hazard will be fully effective or sustainable. The translation of landslide hazard information must consider whether the proposed measures influence the degree of risk to people, property or both. Some measures may be more appropriate than others depending on whether an area is rural or urban. In all cases, the scientific information used to develop and implement landslide hazard reduction should be considered along with economic, cultural, political, environmental, and societal factors. To illustrate how landslide hazard maps can be transformed into policy and regulation, two examples are discussed. One example involves large-scale timber management where landslide hazard can produce adverse economic and environmental consequences. The other example involves an urban setting where both people and property are at risk from landslide occurrence. Landslide hazard maps defining susceptibility for different types of landslides served as the basis for developing and implementing actions to reduce landslide hazard. In both cases, the methodologies used to develop maps with landslide hazard information are secondary to how the information was used to develop effective policy and regulations. 


\section{Integrating landslide hazard information into the local planning process}

Keefer and Larsen (2007) point out that despite advances in landslide assessment and mitigation methods, the growth in world population and the expansion of urban areas onto steep slopes suggest landslides will continue to cause fatalities and property destruction. While societal trends and market forces are significant factors governing where the population and infrastructure of a country is concentrated, it is at the local level of counties, townships, and communities where decisions are made which have the most direct impact on people's vulnerability to landslides. The local planning level is where engineering measures, restrictive zonation, and similar measures can most effectively incorporate knowledge of landslide hazard present within the local landscape.

Schuster and Kockelman (1996) identified four approaches to reduce the risk from landslide hazards. These include: (1) restricting development where land is prone to landslides; (2) enacting codes to govern how excavation, grading, landscaping and construction are done; (3) incorporating physical measures in to designs to prevent or control landslides; and (4) establishing systems to warn people of impending landslide movement. In terms of planning policy, any actions under these approaches may be addressing prospective land uses for undeveloped land or addressing land with existing uses in place (Schwab et al., 2005).

Development regulations that can be used by planners to reduce the risk from landslide hazards include zoning, use restrictions, grading ordinances, maintenance requirements, and development standards (Schwab et al., 2005). Zoning designates the categorical uses allowed on land within a community. Use restrictions are akin to zoning by specifying what uses would be allowed and also describing the conditions associated with their being permitted. Grading ordinances are important during development to avoid altering a slope in a manner that increases the likelihood of landslide movement. A development in a landslide-prone area can need maintenance requirements that ensure the long-term stability of the slope. These maintenance requirements include many of the geotechnical and engineering measures such as retaining walls and drainage commonly associated with landslide remediation (Cornforth, 2005). Development standards can involve clustering buildings on the more stable parts of a subdivision to retain the same overall number of dwellings or requirements ensuring the safety and sustainable operation of infrastructure such as water lines and power cables needed within the development.

\subsection{Resource planning in a rural area}

The Forest Service, an agency of the Federal government, is responsible for the management of about 77 million hectares of land primarily in the western United States and Alaska (DeGraff, 2005). The agency is directed by laws and regulations to plan and administer this land for a variety of public purposes and uses. A primary purpose extending from the time National Forests were created in 1897 is to ensure a sustainable flow of timber. Beginning in the 1970s, it was legally mandated that each National Forest should have a land and resource management plan commonly referred to as a Forest Plan (DeGraff, 2005). The Forest Plan is equivalent to a County-wide plan. Project-specific plans to implement particular actions are done within the context established under the Forest Plan. So, individual timber sale plans are analogous to plans for proposed developments. For timber management, the Forest Plan allocates the areas where timber management will be the primary use or excluded due to specific physical or regulatory conditions. The Forest Plan also establishes the requirements for how timber management would be accomplished. Individual timber sales are planned to implement the Forest Plan objectives and procedures for a specific area within the National Forest (DeGraff, 1985).

The potential for slope movement involving a variety of landslide types is significant on most National Forests because they commonly encompass hilly to mountainous landscapes. Intense rainfall, rain-on-snow events, earthquakes, and volcanic eruptions have all been landslidetriggering mechanisms affecting National Forests in recent years (DeGraff, 2005). Consequently, planning must consider how proposed actions might increase the likelihood of slope movement. Timber harvesting, a primary activity which involves altering vegetation and road building, is a management action where careful planning is required to prevent or limit landslide occurrence.

At its simplest, timber management is cutting a tree in the forest large enough to be transported to a mill where it is transformed into a quantity of lumber. Then either by sprouting of a seed from nearby trees or planting a seedling grown in a nursery, a new tree begins to grow in the place where the large tree was cut. Depending on site conditions and tree species, another large tree will be available for harvest again in 60 to $80 \mathrm{yr}$. A forestry specialist, known as a silviculturalist, prepares prescriptions that govern the forestry activities that will take place over time. The guidance in the prescriptions ensures that at some future point new trees will be present at a size similar to those being harvested today. Sustainable timber management commonly involves harvesting large trees from within $10 \mathrm{~s}$ to $100 \mathrm{~s}$ of hectares (ha) of forested land. A variety of methods and mechanical devices are used. Harvest units can range from cutting an individual tree selected from within a stand of trees to 15 ha blocks which are clear-cut with all the trees present being removed.

In general, the fewer trees left after harvest, the greater the susceptibility to landslide movement on landslide-prone slopes (DeGraff, 1985). Greenway (1987) reviewed the possible interactions of vegetation and slope stability. The most direct relationship was the stabilizing effect of root masses within the soil. This additional soil strength is lost as 
Table 1. Comparison of common land planning actions for reducing landslide hazard as implemented in a rural and urban setting.

\begin{tabular}{|c|c|c|}
\hline $\begin{array}{l}\text { Methods for Landslide } \\
\text { Risk Reduction }\end{array}$ & Timber Management Example & Weber County, Utah Example \\
\hline Zoning & $\begin{array}{l}\text { Re-classifying suitable commercial timber land as } \\
\text { unsuitable where extreme and very high landslide } \\
\text { susceptibility exists }\end{array}$ & $\begin{array}{l}\text { Delineation of natural hazards districts for } \\
\text { landslide, rock fall and debris flow hazards }\end{array}$ \\
\hline Use Restrictions & $\begin{array}{l}\text { Requiring geologic investigation of landslide activ- } \\
\text { ity in proposed timber sales with high and mod- } \\
\text { erate landslide susceptibility and changing condi- } \\
\text { tional use when landslide activity was present }\end{array}$ & $\begin{array}{l}\text { Requiring reports documenting hazard and } \\
\text { proposed mitigation by qualified Engineering } \\
\text { Geologist }\end{array}$ \\
\hline $\begin{array}{l}\text { Maintenance } \\
\text { Requirements }\end{array}$ & $\begin{array}{l}\text { Limited to retaining walls, drainage, and other de- } \\
\text { sign components of timber harvest access roads }\end{array}$ & Debris basins as part of flood control district \\
\hline $\begin{array}{l}\text { Hillside Development } \\
\text { Ordinances }\end{array}$ & NA & $\begin{array}{l}\text { Ordinance specifies consideration of geologic con- } \\
\text { ditions including landslides in plans. Ordinance is } \\
\text { to supplement zoning and subdivision ordinances } \\
\text { for hillside development }\end{array}$ \\
\hline
\end{tabular}

NA - Not applicable to this example.

roots from harvested trees decay and is only replaced by the growth of new tree roots (Zeimer, 1981). Additional studies have documented the details of this aspect of slope stability under forest cover (Sidle et al., 1985; Sidle and Ochai, 2006). Swanson and Dyrness (1975), Jakob (2000), and Dhakal and Sidle (2003) represent some of the studies showing that both the harvest of timber over an area and its associated road building can increase later landslide occurrence.

The Sierra National Forest encompasses nearly 526000 ha within the central Sierra Nevada of California. The forest includes the headwaters of the San Joaquin River and major parts of the upper watersheds for the Merced and Kings rivers and rises from about $275 \mathrm{~m}$ a.s.l. in the foothills to $4263 \mathrm{~m}$ at its highest point, Mt. Humphrey (Sierra NF, 2011). As much as 145690 ha of the forest land is classified as suitable for commercial timber management. It consists mainly of stands consisting of mixed conifer species, ponderosa pine or red fir. Other forest land is unavailable for timber management because of special classification such as designated wilderness or other special areas, being dedicated to other authorized uses, or its being unsuitable due to physical characteristics.

Landslides were recognized as having a significant impact on the management activities of the Sierra National Forest (DeGraff et al., 1984; DeGraff, 1994). An inventory was made of existing landslides based on interpretation of color aerial photography at 1:15840-scale with field checking of about 10 percent of mapped features. This inventory provided the basis for landslide hazard identification. Isopleth mapping of landslides was the method selected for representing the landslide-susceptibility present within the forest land suitable for timber management (DeGraff, 1985). It defines landslide-susceptibility using six categories based on the percent of unit area covered by landslides. These categories defined where different planning measures would be applied to reduce landslide hazard due to timber harvest (Table 1).

The recognized landslide potential from building roads for timber harvesting was addressed in the Forest Plan by providing standards and guidelines for their location, design, construction, and maintenance. This approach is analogous to County plans incorporating national standards such as the Unified Building Code. The landslide-susceptibility categories developed through isopleth mapping were used to address the landslide hazard potential of timber harvesting. In this manner, landslide risk reduction approaches used in planning for area development were applied to forest land with differing landslide hazard potential.

About 3278 ha of the commercial timber land was identified as unstable because landslides covered 50 to 100 percent of a contiguous area. This represented the areas categorized, under isopleth mapping, as having extreme and very high landslide-susceptibility within land otherwise suitable for timber management. Under the Forest Plan, these areas were re-classified as unsuitable for commercial timber management activities (Table 1). This is the equivalent of zoning an area to remain open or undeveloped to avoid initiating landslide activity (Sierra NF, 1991; DeGraff, 1985).

Other commercial timber land was defined as high landslide susceptibility where isopleth mapping found past landslides covering between 30 to 50 percent per unit area. For timber management of these areas under the Forest Plan, a use restriction was applied (Table 1). This use restriction has two components. The first component is evaluation by a geologist of whether any recent landslide activity is present within harvest units or where harvest activity could accelerate local landslide activity. This represents taking into account site development characteristics and 
activity characteristics which is commonly employed in decision making for use restrictions (Schwab et al., 2005). If recent landslide activity is present, the harvest units are deleted from the proposed timber sale (DeGraff, 1985). If no recent landslide activity is present, harvest is designed to avoid exceeding the standard of a modified shelterwood silvicultural prescription. This special prescription represents the second component of the use restriction because it limits the type of harvest that is permissible within this landslide susceptibility zone.

The modified shelterwood prescription differs from a normal shelterwood prescription by specifying the type and number of trees to be maintained following each harvest stage and by never reaching the later stage where all mature trees would be cut. Under the Forest Plan for the Sierra National Forest, the modified shelterwood prescription involved a maximum cut that left 10 to 12 trees with an intervening spacing of 18 to $20 \mathrm{~m}$. These trees should have, at least, a 60 to $76 \mathrm{~cm} \mathrm{dbh} \mathrm{(diameter} \mathrm{at} \mathrm{breast} \mathrm{height).} \mathrm{These} \mathrm{remain-}$ ing trees should also form a live crown ratio of 40 percent or more. Rather than depend on natural regeneration, seedlings were to be planted within the first year after the harvest. The modified shelterwood prescription also left these shelter trees in place for 60 to $90 \mathrm{yr}$. At this future time, the large trees are cut leaving the number, size, spacing, and crown ratio of large trees the same as specified for the initial harvest. The purpose of this modified shelterwood prescription was to ensure sufficient root mass for mechanically reinforcing and buttressing the soil against shallow landslide occurrence (Gray and Megahan, 1981).

Areas of moderate landslide-susceptibility are defined by isopleth mapping as having between 10 to 30 percent landslides per unit area (DeGraff, 1985). Again the use restriction initially is requiring a geologist to look at the proposed harvest activities in relation to evidence of recent or incipient landslide activity (Table 1). When landslide activity is evident, use restrictions could be either eliminating planned harvest units in the affected area or restricting harvest to the modified shelterwood prescription. When no evidence of recent landslide activity is found, there are no use restrictions on harvest method or prescription. However, prompt reforestation following harvest is required to maintain long-term root strength within those harvest units (DeGraff, 1985).

Areas with low and negligible landslide susceptibility are present where isopleth mapping is found to have less than 30 percent landslides (DeGraff, 1985). Within these areas, harvest design and recommendations is based entirely on silvicultural needs because landslide hazard does not pose a critical concern.

\subsection{Land-use planning in an expanding urban area}

During 1983 and 1984, communities from Willard to Salt Lake City, Utah were impacted by debris flows and sedimentladen floods (Wieczorek et al., 1989). Statewide, direct impacts sustained from landslides, debris flows, and floods cost more than $\$ 400$ million over a three month period in the spring of 1983 (Anderson et al., 1985). The most heavily impacted area represented a significant part of the Wasatch Front which extends from Brigham City, on the north, to Provo, on the south, where nearly 80 percent of the population of Utah reside (Albrecht, 2008). In 1950, Utah's population had grown to 530310 people (US Census Bureau, 2011). Development during World War II had only resulted in a 25 percent increase in population. US Census Bureau (2011) data shows Utah experienced a 265 percent population increase to 1461037 between 1950 and 1980 which greatly expanded the Wasatch Front communities where people, residences, roads, and infrastructure were present during the debris flow and flood events of 1983 and 1984.

Historically, communities along the Wasatch Front have experienced damaging debris flow events (Keaton and Lowe, 1998). In some locations, there are events recorded from the early settlement of the area by Mormon pioneers. The conditions associated with the 1983 and 1984 debris flows and floods are recognized as contributing to similar flooding in 1922 and 1952 (Wieczorek et al., 1989). The extensive debris flow and flood occurrences in 1983 and 1984 resulted from a return to more normal wet conditions after an extended period of drier-than-normal conditions from roughly 1925 to 1980 (Fleming and Schuster, 1985). This extended period of infrequent debris flows and flooding coincided with the dramatic increase in population between 1950 and 1980. Consequently, the potential landslide hazard present along the Wasatch Front was not given sufficient consideration as construction of buildings and infrastructure was taking place to serve the growing population. Landslide risk increased not because the landslide hazard was greater, but rather due to an increased vulnerability as defined by more people and property being present (Varnes, 1984).

While there was an immediate emphasis on scientific studies to understand these disastrous events, a related effort was made to improve the planning process for the most heavily impacted and urbanized areas; Weber, Davis, Salt Lake City, Utah, and Juab counties. These counties hired geologists as part of their planning staff (Christenson, 1993). Their expertise was employed in developing new and revised planning measures. The counties also recognized the value of having a geologist on staff to review reports submitted by consultants hired by project proponents.

Weber County is representative of the types of changes made by these counties to more effectively address landslide hazard during the planning process. Weber County, which includes the city of Ogden, Utah, enacted ordinances addressing geologic hazards and requiring geologic reports by 1987 (Christenson, 1987).

The Weber County planning ordinances address landslides and debris flows in the zoning process (Table 1). Their delineation of these hazards is part of the Natural Hazards Overlay Districts defining where studies and reports are required as 
part of the development process (Weber County Zoning Ordinance, 2011a). Thus areas with significant landslide hazard are identified through the zoning process. Potential hazards specifically addressed by Natural Hazards Overlay Districts include surface-fault rupture, landslide, liquefaction, debris flows and alluvial-fan flooding. The maps for defining landslide and debris flow hazards areas in Weber County were developed by Lowe in 1988 and have undergone refinement and improvement to date (Christenson and Shaw, 2008; Elliott and Harty, 2010).

An example of a use restriction under the Weber County zoning ordinance is the requirement for a study to be prepared by an Engineering Geologist for any development proposed in or adjacent to a debris flow hazard area (Table 1). This study must look at past history of debris flows at the site based on subsurface examination of deposited material, an estimation of the drainage basin's potential for generating debris flows and the channel that would carry it to the site, and how any man-made structures upstream might divert or deflect a debris flow. Recommendations must address whether protective structures, channel improvements or other measures should be part of the project. This report must also undergo review and approval by the County Engineer.

Weber County chose to enact a comprehensive hillside development ordinance which includes grading requirements (Table 1). It specifically calls for mitigation measures for parcels of land or lots which are restricted due to geologic considerations and specifies their need to comply with Natural Hazard Overlay District requirements (Weber County Zoning Ordinance, 2011b). The hillside development ordinance provides for outside review of the geologic report submitted by the proponent upon the discretion of the County Engineer. A Hillside Development Review Board considers the report finding, requirements and recommendations.

The Utah Geological Survey, a State agency, has taken a leading role in transforming scientific data into forms suitable for improving the land-use planning process. The Survey produces landslide hazard maps to support land-use planning in different counties. The agency has included reviewing the ways in which geologic hazard information was used as part of planning in other parts of the western United States (Christenson, 1987). Local engineering geology professionals provided suggestions for geologic hazard ordinances and guidelines for engineering geologic reports that might be part of planning ordinances (AEG-Utah, 1986). These guidelines have been refined and supplemented since their initial publication as part of the agencies ongoing efforts in landslide hazard reduction (Hylland, 1996; Giraud, 2005).

In 2002, the State of Utah enacted a professional licensure for geologists. The requirements under this act were further modified by legislation in 2011. These requirements are to ensure that geologists performing many of the studies and actions required under the planning process, as well as other geologic work, have the requisite knowledge, skills, and experience.

\section{The effectiveness of geologic participation in planning}

The preceding two examples illustrate how geologic expertise can be used in County and Town level planning in both a rural and urban setting. They show specific ways that landslide hazard was reduced through the incorporation of landslide information in all aspects of the planning process. More importantly, they show how landslide information is effectively translated by geologists both in developing planning requirements and their implementation. This may raise the question of whether involvement of geologists in the planning process contributes to effective landslide hazard reduction.

One of the few examples describing landslide hazard reduction based on local measures are the hillside building regulations developed in the City and County of Los Angeles, California (Fleming et al., 1979; Olshansky, 1998). Landslides and debris flows were not unknown occurrences in the Los Angeles area prior to the 1950s. The impacts were localized within scattered communities close to the steeper slopes surrounding the Los Angeles Basin. During the post-World War II housing boom and urban expansion of Los Angeles, little attention was given construction practices or geologic conditions that might increase the likelihood of landslides and embankment failures. Consequently, the storms of the winter of 1951-1952 impacted a much more urbanized area encroaching on steeper slopes. The resulting property damage estimated at $\$ 7.5$ million due to landslides and associated erosion and sedimentation served as the impetus for creation of grading regulations. One important feature of these regulations was requiring involvement of individuals with expertise in soils engineering in large grading projects (Fleming et al., 1979).

Fleming et al. (1979) report that these new grading ordinances were put to the test by an intense rainstorm in 1956. Massive erosion and particular landslide problems triggered by this event resulted in modification to the existing grading codes. After this experience, certain grading permits required a geologic report as part of the approval process. These revised regulations were again tested during the winter of 1957-1958. The significant rainfall resulted in significant landslide damage again occurring. In addition to spurring further modification to grading regulations, it also led to requiring evaluation and certification for technical specialists dealing with grading projects. The effectiveness of these enhanced grading regulations was again tested by the rainfall during the winter of 1961-1962. Despite producing less landslide damage that in the past, changes were again made to the grading ordinance. A significant component of this 1963 revision was requiring geologic and engineering involvement in design, construction, and final inspection of a grading project. This was specified as part of certification of project adequacy.

After winter of 1968-1969, an analysis was conducted of damage and slope movement in hillside areas. It provided 
Table 2. Damage associated with the 1969 Storms in Los Angeles (modified from Fleming et al., 1979) in relation to more stringent planning requirements and increasing geologic involvement.

\begin{tabular}{lccc}
\hline & \multicolumn{3}{c}{ Sites Developed in Los Angeles } \\
\cline { 2 - 4 } & Prior to 1952 & $1952-1962$ & $1963-1969$ \\
\hline Total Damage & $\$ 3300000$ & $\$ 2767000$ & $\$ 182400$ \\
Ave. Damage per Site & $\$ 300$ & $\$ 100$ & $\$ 7$ \\
Percent of Sites Damaged & 10.4 & 1.3 & 0.2 \\
\hline Increasing Geologic Involvement in Development Projects
\end{tabular}

a comparison of the damages under the different versions of the hillside grading codes (Table 2). Fleming et al. (1979) reporting on these results indicate the analysis did not separate landslide damage from other types of damage but it is assumed that landslide damage would be reduced by the same proportion as total damage. It is noted that total damage sustained at sites constructed before 1952 was 18 times as much as the total damage at sites developed under the more stringent 1963 regulations. Similarly, damage to development constructed after the 1952 codes and before the 1963 code revisions suffered 15 times as much. On a per site basis, the damage to sites developed before the 1952 regulations averaged, $\$ 300$ per site, sites developed after 1952 and before the 1963 regulatory revision averaged $\$ 100$, and those developed after the 1963 revisions averaged \$7. Certainly, this reduction in total damage and, proportionally, landslide damage results from increasingly stringent regulation, refinement of regulatory enforcement and accumulation of scientific information on how and where landslides hazards existed (Fleming et al., 1979).

Clearly, the degree of involvement by geologic and engineering professionals has been an important element in the successful development and application of these planning ordinances (Table 2). Prior to 1952, there were no requirements that projects benefit in their design and implementation from any professional with soil engineering or geologic knowledge. Development taking place after 1952 and before 1962 required the expertise of soils engineering. This development also had limited geology required after 1952 and geologic reports for certain grading permits after 1956 (Fleming et al., 1979). Development after 1963 was required to have geologic and engineering involvement during design, construction and final inspection. The certification of engineering geologists and preparation of guidance for those practitioners is also important to the quality of development done after 1958. Geologic and engineering expertise was increasingly required for development projects with the establishment of the hillside ordinances and their subsequent revisions. There was also a parallel effort to ensure the competence of those professionals involved from expecting only a general knowledge to requiring a very specific level of knowledge.
Literature review did not find long-term studies of planning actions instituted to reduce landslide losses comparable to the Los Angeles experience. Mader (2005) provides an excellent example of how to use geologic information and geologic personnel in the land use planning for a landslideprone community in northern California. Similarly, Bernknopf et al. (1985) use data from two areas in a northern Virginia county to demonstrate the net economic benefit of geologic maps for future planning. The two case studies include the relevance of geologic maps in avoiding the consequences of geologic hazards including landslides. However, neither study provides specific economic data on loss reduction attributable to the use of landslide hazard information or geologists in the planning process.

\section{Conclusions}

Maps showing the landslide hazard within an area remain a critical component in reducing landslide hazard through the planning process. For successful planning it is just as important to show the spatial distribution of different landslide hazard levels as to show land ownership and topography. Whether in a rural or urban setting, the incorporation of this landslide hazard information into the planning process is improved by a continuing interaction with geological professionals. In planning, their contribution starts with helping to define the technical terms used in the regulations and ordinances and the hazard reduction approaches to be specified when certain conditions favoring landslide occurrence are present. Another valuable contribution by geologists in developing these regulations and ordinances is development of guidelines to satisfy planning requirements and ensure accurate transformation of the landslide hazard maps. As illustrated by both the City of Los Angeles and Weber County experiences, there is a benefit to periodic review of the ordinances and the landslide hazard maps to ensure the best available science continues to underpin these technical components of the planning process.

The geologist's understanding of the limitations of the methodology used for developing the landslide hazard maps can assist the planner in recognizing the degree of risk being 
accepted by the governmental agency and the property owner or project developer. This is an important consideration because in many instances, it will be the local government and property owners that bear a significant cost should a landslide occur. Disclosure of this risk during the planning process also increases the scrutiny of project design not only by the project proponent but also by insurers, investors, and potential buyers.

In most instances, the level of detail needed to properly assess the landslide hazard present and the risk it poses to a particular project requires site-specific study. The geologists assisting the planning agency, either as technical staff members or hired consultants, conduct reviews of projects to ensure required guidelines are followed and submitted findings fully support stated conclusions. In some cases, their reviews would also evaluate the appropriateness of proposed mitigation measures. Geologists conducting these studies for project proponents have a similar role in carrying out their studies adhering to high professional standards and consistent with the current state of the practice.

Geologists involved in any part of the planning process should consider themselves to be educators as much as scientists. This educational aspect involves assisting nongeologists in fully understanding both the findings and their implications. This need extends to planners, engineers, investors, project designers, politicians, and the general public and is unlikely to always be fully successful with everyone involved. Nonetheless, long-term sustainable landslide hazard reduction requires both scientific and educational involvement by geologists. Unless geologists are committed to both the scientific and educational aspects of the planning process, only limited progress will be made in achieving significant and sustainable landslide hazard reduction.

Acknowledgements. The author thanks the two reviewers for their thoughtful comments and suggestions which have contributed to the clarity of this paper.

Edited by: F. Luino

Reviewed by: L. Highland and R. Giraud

\section{References}

AEG-Utah: Guidelines for preparing engineering geologic reports in Utah, Utah Geologic and Mineral Survey Miscellaneous Publication M, Salt Lake City, Utah, 1986.

Albrecht, D. E.: The State of Utah, Population Brief, Trends in the western U.S., Western Rural Development Center, available at: http://wrdc.usu.edu/files/publications/publication/pub_1960427.pdf, last access: 27 November 2011, 2008.

Anderson, L. R., Keaton, J. R., Saarinen, T. F., and Wells II, W. G.: The Utah landslide, debris flows, and floods of May and June 1983, in: Delineation of Landslide, Flash Flood, and Debris Flow Hazards in Utah, edited by: Bowles, D. S., Utah Water Research Laboratory Publication 85/03, Logan, Utah: Utah State University, 3-16, 1985.
Bernknopf, R. L., Brookshire, D. S., Soller, D. R., McKee, M. J., Sutter, J. F., Matti, J. C., and Campbell, R. H.: Societal value of geologic maps, US Geological Circular 1111, 53 pp., 1993.

Chacon, J., Irigaray, C., and Fernandez, T.: Engineering geology maps: landslides and geographical information systems, B. Eng. Geol. Environ., 65, 341-411, 2006.

Christenson, G. E.: Suggested approach to geologic hazards ordinances in Utah, Utah Geologic and Mineral Survey Circular 79, 16 pp., 1987.

Christenson, G. E.: The Wasatch Front County Hazards Geologist program, in: Applications of research from the US Geological Survey Program, Assessment of Regional Earthquake Hazards and risk along the Wasatch Front, Utah, edited by: Gori, P. L., US Geological Survey Professional Paper 1519, 114-120, 1993.

Christenson, G. E. and Shaw, L. M.: Geographic information system database showing geologic-hazard special-study areas, Wasatch Front, Utah, Utah Geological Survey Circular 106, 7 pp., 2008.

Cornforth, D. H.: Landslides in practice: investigations, analysis, and remedial/preventative options in soils, John Wiley \& Sons, Hoboken, New Jersey, 596 pp., 2005.

DeGraff, J. V.: Using isopleth maps of landslide deposits as a tool in timber sale planning, B. Assoc. Eng. Geol., 22, 445-453, 1985.

DeGraff, J. V.: The geomorphology of some debris flows in the southern Sierra Nevada, California, Geomorphology, 10, 231252, 1994.

DeGraff, J. V.: The dilemma of transforming landslide hazard maps into effective policy and regulation, Geol. Soc. Amer. Abstr. Programs, 32, 2000.

DeGraff, J. V.: Landslide hazards and Federal lands: the United States Department of Agriculture Forest Service experience, in: Landslide Hazards and Planning, edited by: Schwab, J. C., Gori, P. L., and Jeer, S., American Planning Association, Planning Advisory Service Report Number 533/534, 154-164, 2005.

DeGraff, J. V., McKean, J., Watanabe, P. E., and McCaffery, W. F.: Landslide activity and groundwater conditions: insights from a road in the central Sierra Nevada, California, Transport Res. Rec., 965, 32-37, 1984.

Dhakal, A. S. and Sidle, R. C.: Long-term modelling of landslides for different forest management practices, Earth. Surf. Process. Land., 28, 853-868, 2003.

Elliott, A. H. and Harty, K. M.: Landslide maps of Utah, Utah Geological Survey Map 246DM, 2010.

Fleming, R. W. and Schuster, R. L.: Implications of the current wet cycle to landslides in Utah, in: Delineation of Landslide, Flash Flood, and Debris Flow Hazards in Utah, edited by: Bowles, D. S., Utah Water Research Laboratory Publication 85/03, Logan, Utah, Utah State University, 19-28, 1985.

Fleming, R. W., Varnes, D. J., and Schuster, R. L.: Landslide hazards and their reduction, Am. Plan. Ass. J., 45, 428-439, 1979.

Giraud, R. E.: Guidelines for the geologic evaluation of debris-flow hazards on alluvial fans in Utah, Utah Geological Survey Miscellaneous Publication, 05-6, 16 pp., 2005.

Gray, D. H. and Megahan W. F.: Forest vegetation removal and slope stability in the Idaho Batholith, USDA Forest Service Research Paper INT-271, 23 pp., 1981.

Greenway, D. R.: Vegetation and slope stability, in: Slope Stability, Geotechnical Engineering and Geomorphology, edited by: Anderson M. G. and Richards K. S., Chicester, UK: John Wiley \& 
Sons, 187-230, 1987.

Hylland, M. D.: Guidelines for evaluating landslide hazards in Utah, Utah Geological Survey Circular 92, 18 pp., 1996.

Jakob, M.: The impact of logging on landslide activity in Clayoquot Sound, British Columbia, Catena, 38, 279-300, 2000.

Keaton, J. R. and Lowe, M.: Evaluating debris-flow hazards in Davis Countym Utah: engineering versus geological approaches, in: A Paradox of Power: Voices of Warning and Reason in the Geosciences, edited by: Welby, C. W. and Gowan, M. E., Geological Society of American Reviews in Engineering Geology 12, 97-121, 1998.

Keefer, D. K. and Larsen, M. C.: Assessing landslide hazards, Science, 316, 1136-1138, 2007.

Lowe, M.: Weber County geologic-hazard special-study-area maps, Weber County Planning Department, Ogden, Utah, scale $1 ; 24,000,1988$.

Mader, G.: A model of effective use of geology in planning, Portola Valley, California, in: Landslide Hazards and Planning, edited by: Schwab, J. C., Gori, P. L., and Jeer, S., American Planning Association, Planning Advisory Service Report Number 533/534, 96-112, 2005

Olshansky, R. B.: Regulation of hillside development in the United States, Environ. Manage., 22, 383-392, 1998.

Schwab, J. C., Gori, P. L., and Jeer, S.: Landslide Hazards and Planning, American Planning Association, Planning Advisory Service Report 533/534, 208 pp., 2005.

Schuster, R. L. and Kockelman, W. J.: Principles of landslide hazard reduction, in: Landslides Investigation and Mitigation, edited by: Turner, A. K. and Schuster, R. L., Washington, DC, National Academy Press, 91-105, 1996.

Sidle, R. C. and Ochiai, H.: Landslides processes, prediction, and land use, Water Resources Monograph 18, American Geophysical Union, Washington, DC, 312 pp., 2006.
Sidle, R. C., Pearce, A. J., and O'Loughlin, C. L.: Hillslope stability and land use. Water Resources Monograph 11, American Geophysical Union, Washington, DC, 140 pp., 1985.

Sierra NF: Final Environmental Impact Statement, Forest Land and Resource Management Plan, Sierra National Forest, Clovis, California, 3-57-3-58, 1991.

Sierra NF: Sierra National Forest, available at: http://www.fs.usda. gov/sierra/, last access: 27 November 2011, 2011.

Swanson, F. J. and Dyrness, C. T.: Impact of clear-cutting and road building on soil erosion by landslides in the western Cascade Range, Oregon, Geology, 3, 393-396, 1975.

US Census Bureau: Resident population and apportionment of the US House of Representatives-Utah, available at: http://www. census.gov/dmd/www/resapport/states/utah.pdf, last access: 27 November 2011, 2011.

Varnes, D. J.: Landslide hazard zonation: a review of principles and practice, UNESCO, Paris, 1984.

Weber County Zoning Ordinance: Chapter 38, Natural Hazards Overlay Districts, http://www.co.weber.ut.us/mediawiki/ index.php/Natural_Hazards_Overlay_Districts, last assesse: 23 July 2011, 2011a.

Weber County Zoning Ordinance: Chapter 36b, Natural Hazards Overlay Districts, available at: http://www.co.weber.ut.us/ mediawiki/index.php/Hillside_Development_Procedures_and_ Standards, last assess: 23 July 2011, 2011 b.

Wieczorek, G. F., Lips, E. W., and Ellen, S. D.: Debris flows and hyperconcentrated floods along the Wastach Front, Utah, 1983 and 1984, B. Assoc. Eng. Geol., 26, 191-208, 1989.

Zeimer, R. R.: Roots and stability of forested slopes, Int. Assoc. Hydrol. Sci. Publ., 132, 343-361, 1981. 